\title{
Measurement of Glutamate-Oxalacetate Transaminase Activity in Human Blood Serum Using Differential Pulse Anodic Stripping Voltammetry
}

\author{
Saadallah T. Sulaiman Haitham A. Al-Wahab Ramiz S. Alkasir \\ Department of Chemistry \\ College of Science \\ Mosul University
}

(Received 23/6/2008; Accepted 13/7/2010)

\begin{abstract}
A new electrochemical method for measuring the activity of glutamate-oxalacetate transaminase (GOT) in human blood serum was developed based on the appearance of a voltammetric peak current of oxalacetate at $-0.4 \mathrm{~V}$ vs. $(\mathrm{Ag} / \mathrm{AgCl}, 3 \mathrm{~mol} / \mathrm{L} \mathrm{KCl})$ as a reference electrode using phosphate buffer ( $\mathrm{pH}$ 7.4) as a supporting electrolyte. It is successfully applied for measuring GOT activity in certain diseases such as: Liver cirrhosis and Myocardial infarction, as well as normal cases. The results of our proposed method were compared with those obtained from colorimetric method for 38 specimens of human blood serum. A good relationship between the two methods were obtained with a correlation coefficient $(r=0.9976)$.
\end{abstract}

\section{قيلس فعالية النزم كلوتاميت -لوكزالولسيتيت ترالن المينيزفي مطل م الإنسلن بلستخدلم

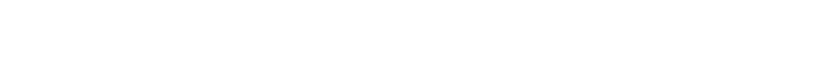

\section{الملغص}

يتضمن البهث إيجادطريقة كهروكيميائية جدية لقيلس فعالية أنزيم كلوتلميت -اوكزالولسيتيت ترانس

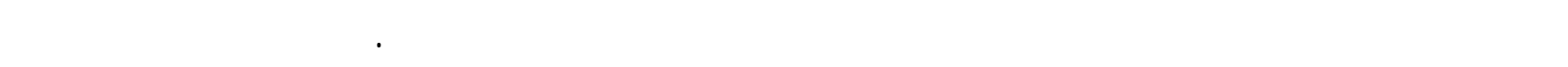

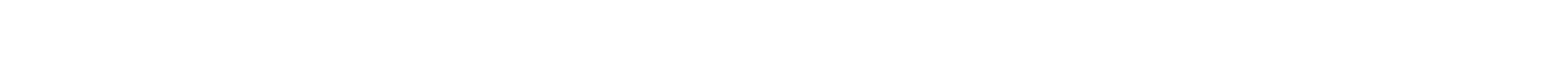

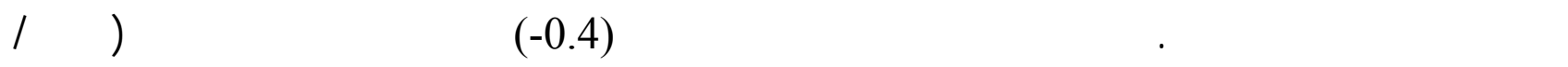

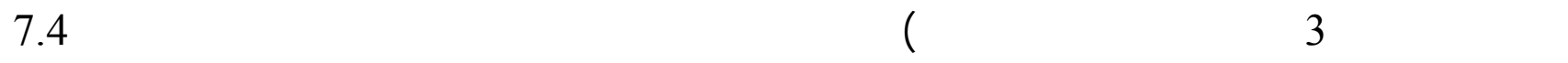

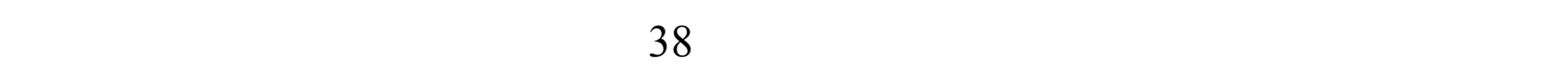
ولخرين مصابين بحالات مرضية معينة مل: تلفي الكبد المزمن و الاحشاء القلب.

*م إفاه بالمؤتمر العلهي الأول للكيمياء المنعد بتاريخ 22-23 نيسان 2008 في قم الكيمياء /كلية العلوم/جلمعة الموصل 


\section{وقد مت الحصول على ظابق غطي بين النتائج المستحصلة بطريقتا المقرحة مع النتائج المقلسة باطاريقة اللونية وكلنت العلاقة خطية بينهما وبمعلمل ارتبطل مقداره (r = 0.9976).}

\section{INTRODUCTION}

Glutamate-oxalacetate transaminase GOT also known as aspartate aminotransferase (AST) has the ability to catalyze the following enzymatic reaction as shown in equation (1) :

$$
\alpha \text {-Oxogltarate }+\mathrm{L}-\text { Aspartate } \stackrel{\mathrm{GOT}}{\longrightarrow} \mathrm{L} \text { - Glutaminate }+ \text { Oxaloacetate }
$$

Transamination reactions play significant role in intermediary metabolism. They require pyridoxal phosphate as a coenzyme for their catalytic activity (Nelson and Cox, 2005). Aspartate aminotransferase found in many animals and plants tissues and its activity is especially high in mammalian heart and liver (Zilva and Pannal, 1984). The enzyme exists in two distinct isoenzyme forms in mammalian tissues, the mitochondrial form and the cytoplasmic form. However, GOT levels in human blood serum are used in clinical diagnosis of liver and heart diseases (Burtis and Ashwood, 1994). Serum GOT levels in healthy cases are low, but the levels are significantly elevated in a number of clinical conditions such as acute and chronic hepatitis, obstructive jaundice, carcinoma of liver, myocardial infarction and muscular dystrophy (Sherwin and Sohenes, 1996). Therefore, determination of serum GOT level has great clinical and diagnostic significant. It has applications in couple enzyme reactions for the measurement of metabolite levels in biological fluids (Kim et al., 2001; Maitra et al., 2005).

Several methods were available for measuring GOT activity, the colorimetric method based on monitoring the concentration of oxalacetate hydrazone formed with 2,4dinitrophenylhydrazine (Reitman and Frankel, 1957). Stripping voltammetry is a very sensitive electroanalytical technique that used for trace analysis. It has a lowest determination limits in comparison with other commonly used electroanalytical techniques. The three most commonly used variations of stripping voltammetry used for quantitative determination of electroactive compounds are: anodic stripping voltammetry (ASV), cathodic stripping voltammetry (CSV), and adsorptive voltammetry (AdSV) (Wang, 1990). Due to the high sensitivity and selectivity of stripping voltammetry, it has the ability to use it with another voltammetric technique such as square-voltammetry (SWV) or differential pulse voltammetry (DPV). (Brett and Bret, 1993)

In the present work, differential pulse anodic stripping voltammetry (DPASV) was used for measuring GOT activity in the real specimens of human blood serum as a best voltammetric technique for this purpose.

\section{Apparatus}

\section{EXPERIMENTAL}

The electrochemical studies were carried on EG\&G 384 B Polarographic Analyzer with hanging mercury dropping electrode (HMDE) as a working electrode, $(\mathrm{Ag} / \mathrm{AgCl}, 3 \mathrm{M}$ $\mathrm{KCl}$ ) as a reference electrode, and Pt wire as an auxiliary electrode. The colorimetric studies were performed on Cecil UV-Vis CE 10211 digital single beam spectrophotometer. 
Temperature control was performed using thermostatic water bath type radiometer VTS 13 for electrochemical measurement, and thermostatic water bath model SB 10 from British Grants Instruments Limited for colorimetric measurements.

\section{Chemicals and reagents}

The GOT contains phosphate buffer $(100 \mathrm{mmol} / \mathrm{L}, \mathrm{pH}$ 7.4), L-aspartate $(100$ $\mathrm{mmol} / \mathrm{L}), \alpha$-oxoglutarate $(2.0 \mathrm{mmol} / \mathrm{L})$ in a total volume of $100 \mathrm{ml}$ Sodium Hydroxide $(4.0$ $\mathrm{N})$ in a total volume of $100 \mathrm{ml}$, and 2,4-dinitrophenylhydrazine $(2.0 \mathrm{mmol} / \mathrm{L})$ in a total volume of $100 \mathrm{ml}$ were supplied from Randox laboratories Ltd. Company (Randox, Cat. No. AS 147). (0.2 mol/L) Phosphate buffer $\mathrm{pH} 7.4$ was prepared by dissolving $3.4836 \mathrm{~g}$ of dipotassium hydrogen phosphate $\mathrm{K}_{2} \mathrm{HPO}_{4}$ and $2.7218 \mathrm{~g}$ of potassium dihydrogen phosphate $\mathrm{KH}_{2} \mathrm{PO}_{4}$ in a total volume of $100 \mathrm{ml}$ deionized distilled water. $\left(10^{-3} \mathrm{~mol} / \mathrm{L}\right)$ oxalacetate stock solution was prepared freshly by dissolving $0.0013 \mathrm{~g}$ of oxalacetic acid in a total volume of $100 \mathrm{ml}$ deionized distilled water. $(0.4 \mathrm{~N}) \mathrm{NaOH}$ solution was prepared freshly from $\mathrm{NaOH}$ stock solution. For quality control tests, three human assayed serum levels were prepared freshly by dissolving each vial of lypophilized serum with exactly $5 \mathrm{ml}$ of deionized distilled water, then waiting for $30 \mathrm{~min}$ to complete dissolving process by keeping all of them out of light before use. All real specimens of human blood serum were collected from The Republic Hospital in Mosul, and then they are prepared and assayed within an hour, otherwise serum samples should be kept frozen.

\section{Procedure}

For voltammetric measurements, three-electrode cell has contained $5 \mathrm{ml}$ of $0.2 \mathrm{~mol} / \mathrm{L}$ phosphate buffer $\mathrm{pH} 7.4$ and $0.1 \mathrm{ml}$ of stock solution GOT buffer. The enzymatic reaction was initiated by addition $0.1 \mathrm{ml}$ of human blood serum, the solution was de-aerated for $30 \mathrm{~s}$ using $\mathrm{N}_{2}$ gas and the voltammogram was recorded after affixing the potential range from 0.1 to- $0.6 \mathrm{~V}$ vs. $(\mathrm{Ag} / \mathrm{AgCl})$. The activity of GOT was determined depending on the increment in the current value of the reduction wave of oxalacetate that produced through the enzymatic reaction which appeared at $-0.4 \mathrm{~V}$ vs. $(\mathrm{Ag} / \mathrm{AgCl})$. Moreover, the electrochemical cell was thermostated at $37^{\circ} \mathrm{C}$.

For colorimetric method, the sample cuvette contained $0.5 \mathrm{ml}$ of GOT buffer and $0.1 \mathrm{ml}$ of a real sample of human serum thermostated at $37^{\circ} \mathrm{C}$ for $30 \mathrm{~min}$, then $0.5 \mathrm{ml}$ of 2,4-dinitrophyenylhydrazine was added and left for $20 \mathrm{~min}$ at $20^{\circ} \mathrm{C}$ for complete reaction, and $5.0 \mathrm{ml}$ of $0.4 \mathrm{~N} \mathrm{NaOH}$ was added finally to complete the colorimetric reaction. The absorbance of sample $\left(\mathrm{A}_{\text {sample }}\right)$ was measured at $546 \mathrm{~nm}$ against a blank solution.

\section{RESULTS AND DISCUSSION \\ Voltammetric behavior of oxalacetate produced during GOT enzymatic reaction}

The optimum conditions were examined using DPASV as shown in Tables (1-4) as follows: deposition time $0 \mathrm{~s}$, conditioning time $10 \mathrm{~s}$, equilibrium time $5 \mathrm{~s}$, and scan rate 400 $\mathrm{mV} / \mathrm{s}$. The voltammetric cell was thermostated at $37^{\circ} \mathrm{C}$, the solution de-aerated by passing

$\mathrm{N}_{2}$ gas through it for $240 \mathrm{~s}$. The calibration curve was constructed using serial additions of $10^{-3} \mathrm{~mol} / \mathrm{l}$ oxalacetic acid solution, the linearity appeared in the range from 0 to $0.2 \mathrm{ml}$. The linear equation is: $y=122.2 x-0.0005$; where $\mathrm{y}$ is the reduction peak current of oxalacetate, Ip (nA) and $x$ is the volume of oxalacetic solution (ml), as shown in Fig. (1). The GOT activity in human blood serum was calculated using equation (2) in order to detect the 
activity of GOT in the real specimens of human blood serum using DPASV. However, one unit of GOT activity (U/l) is equal to the rate of production of one micromole of oxalacetate per one minute under the assay conditions.

$$
\text { GOT Activity }(\mathrm{U} / \mathrm{l})=\left[\frac{x \times 0.001}{5.2+x}\right] * 10^{6}
$$

According to the enzymatic reaction of GOT, the oxalacetate which has been produced during this reaction by using our proposed method DPASV gives us the differential pulse anodic stripping voltammogram at $-0.4 \mathrm{~V}$ vs. $(\mathrm{Ag} / \mathrm{AgCl})$ in phosphate buffer $\mathrm{pH} 7.4$ after human blood serum addition as shown in Fig. (2B). Moreover, Fig. 2A represents the differential pulse anodic stripping voltammogram for phosphate buffer $\mathrm{pH} 7.4$ before human serum addition; this indicates the major role of oxalacetate produced through the enzymatic reaction.

Table 1: Effect of deposition time on the reduction current of oxalacetate

\begin{tabular}{|c|c|c|c|c|c|c|}
\hline $\begin{array}{c}\text { Deposition } \\
\text { time (s) }\end{array}$ & 0 & 2 & 4 & 6 & 8 & 10 \\
\hline Ip (nA) & 10.880 & 10.431 & 9.910 & 9.880 & 9.730 & 9.720 \\
\hline
\end{tabular}

Table 2: Effect of conditioning time on the reduction current of oxalacetate

\begin{tabular}{|c|c|c|c|c|c|c|}
\hline $\begin{array}{c}\text { Conditioning } \\
\text { time (s) }\end{array}$ & 0 & 2 & 4 & 6 & 8 & 10 \\
\hline Ip (nA) & 10.900 & 11.480 & 11.490 & 11.700 & 11.730 & 12.340 \\
\hline
\end{tabular}

Table 3: Effect of equilibrium time on the reduction current of oxalacetate

\begin{tabular}{|c|c|c|c|c|c|c|}
\hline $\begin{array}{c}\text { Equilibrium } \\
\text { time (s) }\end{array}$ & 5 & 7 & 9 & 11 & 13 & 15 \\
\hline Ip (nA) & 11.550 & 11.510 & 11.410 & 11.080 & 10.570 & 10.030 \\
\hline
\end{tabular}

Table 4: Effect of scan rate on the reduction current of oxalacetate

\begin{tabular}{|c|c|c|c|c|}
\hline Scan rate (mV/s) & 100 & 200 & 300 & 400 \\
\hline Ip (nA) & 9.390 & 10.720 & 11.080 & 11.200 \\
\hline
\end{tabular}




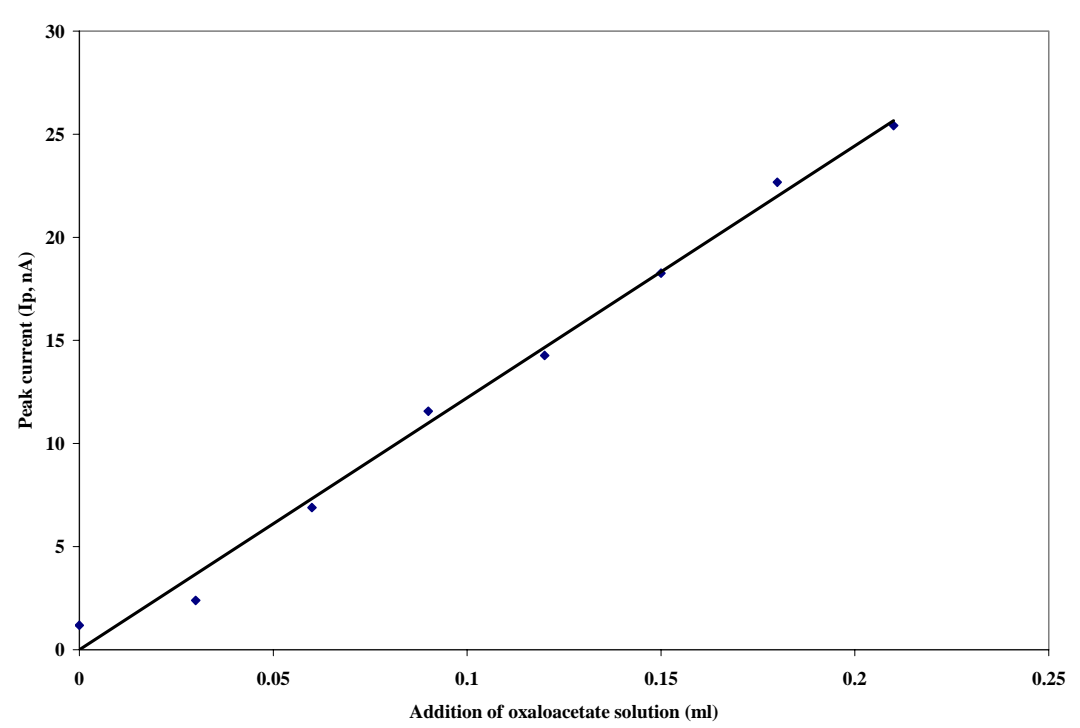

Fig.1: Calibration curve between the reduction wave current value of oxalacetate(Ip) and the series volume additions of $10^{-3} \mathrm{~mol} / \mathrm{L}$ oxalacetate solution.

\section{Effect of human blood serum amount}

$0.1 \mathrm{ml}$ of a real specimen of human blood serum was selected as the optimum value in our proposed method DPASV. A set of additions ranging from 0.02 to $0.1 \mathrm{ml}$ of human serum were added into the voltammetric cell. The later contains $5 \mathrm{ml}$ of phosphate buffer pH 7.4 and $0.1 \mathrm{ml}$ GOT buffer, respectively. The optimum value gives a maximum value of the reduction wave of oxalacetate at $-0.4 \mathrm{~V}$ vs. $(\mathrm{Ag} / \mathrm{AgCl})$ as shown in Table 5.

Table (5): Effect of human blood serum amount on the reduction wave of oxalacetate.

\begin{tabular}{|c|c|c|c|c|c|}
\hline $\begin{array}{c}\text { Volume addition of } \\
\text { serum (ml) }\end{array}$ & 0.02 & 0.04 & 0.06 & 0.08 & 0.10 \\
\hline Ip (nA) & 6.180 & 7.010 & 9.190 & 11.150 & 11.330 \\
\hline
\end{tabular}

\section{Comparison study between DPASV and colorimetric methods}

The comparison between our proposed method DPASV and colorimetric method were carried out using 38 samples which were divided into normal cases and patients suffering from different diseases such as: Liver cirrhosis and Myocardial infarction. Table 6 shows the data which showed a consistent difference in the GOT activity between our proposed method and colorimetric method in normal and patient cases. Figure 3 displays the linear relationship for measuring GOT activity in human blood serum using DPASV and colorimetric methods with correlation coefficient $(\mathrm{r}=0.9976)$. The latter indicates a good agreement between these methods. The relationship between two methods could be represented by equation (3):

GOT activity by DPASV method $=[-0.2585+(0.7263 *$ GOT activity by colorimetric method] 
Table 6: GOT activity measured by DPASV and colorimetric methods in normal and patient cases.

\begin{tabular}{|l|c|c|}
\hline \multicolumn{1}{|c|}{ Samples } & $\begin{array}{c}\text { GOT activity by } \\
\text { DPASV method (U/I) }\end{array}$ & $\begin{array}{c}\text { GOT activity by } \\
\text { colorimetric method (U/l) }\end{array}$ \\
\hline Normal $(\mathrm{n}=21)$ & 5.123 & 6.475 \\
\hline Liver cirrhosis $(\mathrm{n}=8)$ & 25.235 & 37.788 \\
\hline Myocardial infarction $(\mathrm{n}=9)$ & 50.495 & 69.068 \\
\hline
\end{tabular}
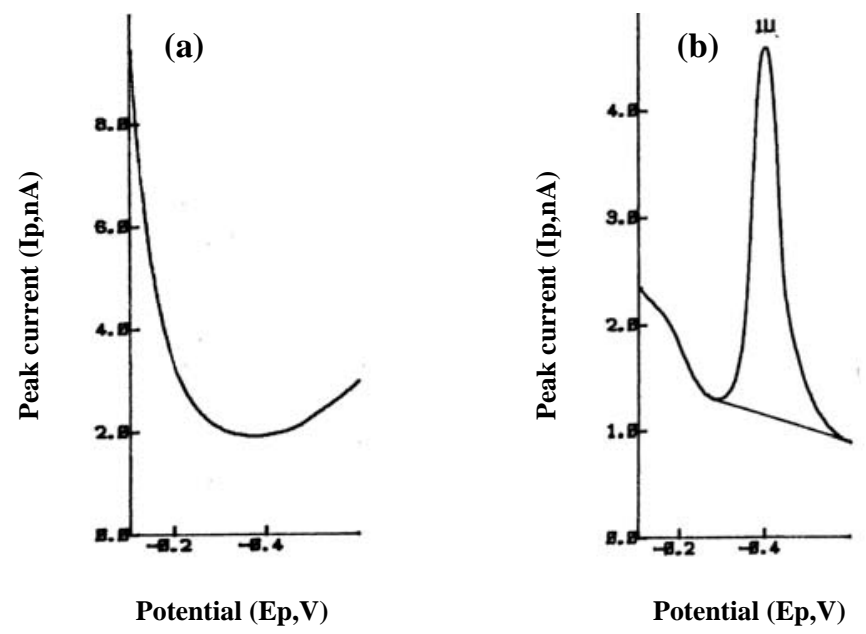

Fig. 2: Differential pulse anodic stripping voltammograms of oxaloacetate in phosphate buffer $\mathrm{pH} 7.4$ as: (a) before human blood serum addition, (b) after human blood serum addition.

\section{Quality control study}

To examine the accuracy and reproducibility control from the DPASV and colorimetric methods, quality controls Levels 1,2 and 3 were assayed respectively. Table 7 shows that the results are displayed a good agreement between our proposed method DPASV and colorimetric method. 
Table 7: Quality control of GOT activity in human serum measured by DPASV and colorimetric methods.

\begin{tabular}{|l|c|c|c|}
\hline Quality control vials & $\begin{array}{c}\text { Range } \\
\text { (U/I) }\end{array}$ & $\begin{array}{c}\text { GOT activity } \\
\text { measured by } \\
\text { DPASV method (U/I) }\end{array}$ & $\begin{array}{c}\text { GOT activity } \\
\text { measured by } \\
\text { colorimetric method } \\
\text { (U/I) }\end{array}$ \\
\hline Level 1 human serum & $11-17$ & 16 & 11.4 \\
\hline Level 2 human serum & $19-29$ & 25 & 17.9 \\
\hline Level 3 human serum & $45-70$ & 60 & 43.3 \\
\hline
\end{tabular}

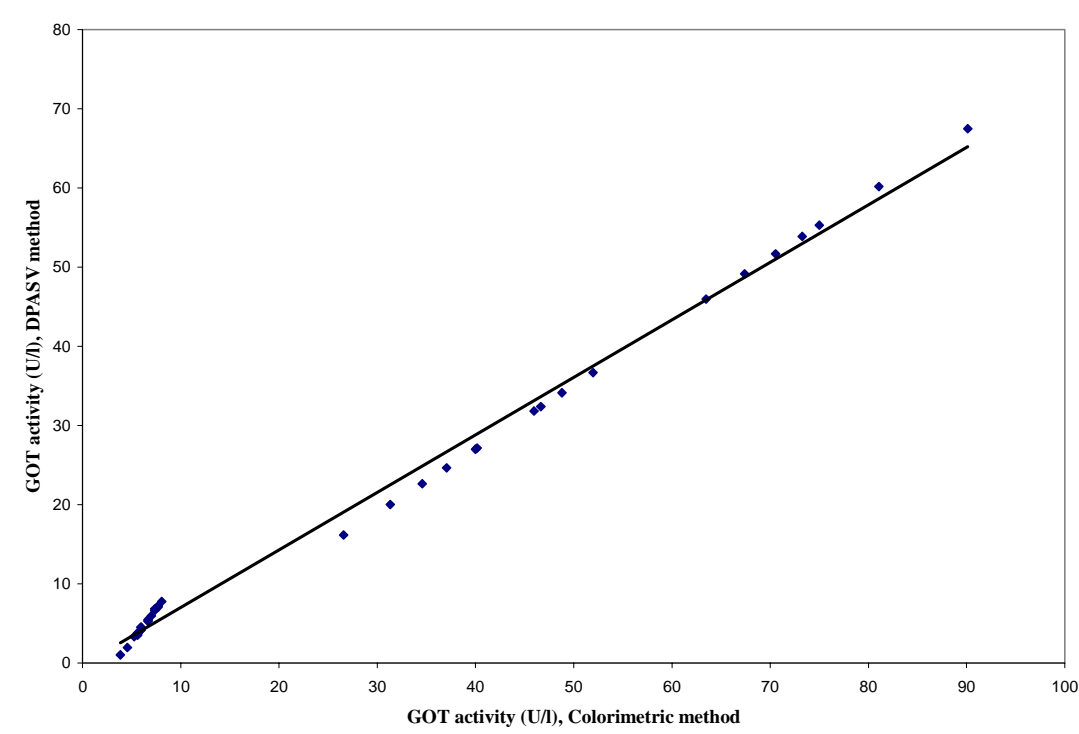

Fig. 3: The linear relationship between DPASV and colorimetric methods that used for determination of serum GOT activity in normal and patient cases.

\section{REFERENCES}

Brett, C. M. A.; Bret, A.M.O. (1993). "Electrochemistry: Principles, Methods and Applications", Oxford University Press, $74 \mathrm{p}$.

Burtis, C. A.; Aswood, E.R. (1994). "Textbook of Clinical Chemistry". 4th edn., Saunders Press, Inc., Philadelphia, pp. 1449-1512.

Christensen, P.A.; Hamnett, A. (1993). "Techniques and Mechanisms in Electrochemistry". Springer, pp. 115-223.

Kim, W.R.; Gross, J.B.; Poterucha, J.J.; Locke, G.R.; Dickson, E.R. (2001). Outcome of hospital care of liver disease associated with hepatitis $\mathrm{C}$ in the United States., Hepatology, 33, 201-206. 
Maitra, S.R.; Shapiro, M. J.; Bhaduri, S.; El-Maghrabi, M. R. (2005). Effect of chemically modified tetracycline on transforming growth factor-[beta]1 and caspase-3 activation in liver of septic rats, Med. Crit. Care, 33, 1577-1581.

Sherwin, J. B.; Sohenes, J. E. (1996). "Clinical Chemistry". 4th edn., WB Saunders Company, Inc., Philadelphia, pp. 505-527.

Nelson, D.L.; Cox, M.M. (2005). "Lehninger Principles of Biochemistry". 5th edn., W. H. Freeman and Company, New York, $660 \mathrm{p}$.

Wang, J. (1990). Recent advances in stripping analysis. Fresenius J. Anal. Chem., 337, 498511.

Zilva, J. F.; Pannal, P. R. (1984). "Clinical Chemistry in Diagnosis and Treatment". 5th edn., Loyd-Luke LTD., London, pp. 336-337. 